\title{
Tanda Lahir "Strawberry" pada Bayi bantu Temukan Terapi Kanker Baru
}

\author{
Dwi Retno Sari \\ Program Studi Magister Farmasi, Fakultas Farmasi, Universitas Padjadjaran, Sumedang, Jawa Barat. \\ email: dwi180232@mail.unpad.ac.id \\ (Submit 26/5/2019, Revisi 16/7/2019, Diterima 18/7/2019)
}

\begin{abstract}
Abstrak
Tanda lahir sering dimiliki pada bayi yang baru lahir, tanda lahir sendiri berupa bercak dengan beragam warna dan bentuk tertentu. Sebagian besar tanda lahir disebabkan oleh adanya pembuluh darah yang abnormal atau tidak normal yang berada dibawah kulit yang biasanya timbul berwarna ungu, merah muda, atau biru. Tanda lahir seperti ini lebih dikenal dengan tanda lahir vaskular, tanda lahir ini biasanya sering dijumpai pada area wajah, leher, dan kepala. Dalam min review ini dijelaskan terkait tanda lahir "Strawbery" dapat membantu menemukan terapi kanker baru.
\end{abstract}

Kata kunci : tanda lahir, strawbery, kanker

\section{Outline}

- Pendahuluan

- Tanda Lahir Strawberry (Hemangioma)

- Ciuman Malaikat (Angel's Kisses)

- Noda Anggur

- Kasus tanda lahir strawberry di Indonesia

- Penelitian dikaitkan dengan kanker

- Terapi menggunakan teknik stem cell

- Terapi kanker konvensional

- Konsep terapi kanker baru

- Strawberry dan sel kanker

- Kesimpulan

- Daftar Pustaka

\section{Pendahuluan}

Tanda lahir sering dimiliki pada bayi yang baru lahir, tanda lahir sendiri berupa bercak dengan beragam warna dan bentuk tertentu.

Sebagian besar tanda lahir disebabkan oleh adanya pembuluh darah yang abnormal atau tidak normal yang berada dibawah kulit yang biasanya timbul berwarna ungu, merah muda, atau biru.

Tanda lahir seperti ini lebih dikenal dengan tanda lahir vaskular, tanda lahir ini biasanya sering dijumpai pada area wajah, leher, dan kepala. Tanda lahir ini terbagi menjadi beberapa jenis yaitu : 


\section{Tanda Lahir Strawberry (Hemangioma)}

Bayi memiliki tanda lahir jenis ini akan memiliki bercak merah menyerupai strawberry dikulit, namun jika pembuluh darahnya tidak normal (abnormal) menyerang bagian yang lebih dalam dibawah kulit, maka bercak yang muncul akan berwarna biru atau ungu.

\section{Ciuman Malaikat (Angel's Kisses)}

Tanda lahir ini keberadaannya ditandai oleh bercak tipis berwarna merah muda atau merah dikulit yang menyerupai warna ikan salmon, dan lebih cenderung muncul pada kulit diantara alis, kelopak mata atas, bibir atas dan belakang leher.

\section{Noda Anggur}

Terjadinya bercak merah muda kemerahan terlihat sejak bayi, bercak tersebut akan berubah menjadi merah keunguan. Noda anggur sering timbul disatu sisi tubuh dan biasanya terjadi pada wajah, dada dan punggung. ${ }^{1}$

\section{Kasus tanda lahir strawberry di Indonesia}

Pada tahun 2017 terjadi kasus strawberry birthmarks (Tanda lahir strawberry atau lebih dikenal dengan Hemangioma di Indonesia pada bayi Luna berusia 20 bulan terdapat bercak kemerahan di dahi kiri atas.

Awalnya saat luna lahir bercak itu tidak ada, setelah seminggu baru kelihatan dan kelamaan makin terlihat jelas. Dan setalah menginjak usia 1 tahun hemangioma yang diderita Luna mulai sedikit mengempis dan warnanya nampak memudar, dan kasus hemangioma bisa menjadi parah tergantung pada jenis dan ukuran hemangioma, ada yang menetap dan ada yang bisa hilang dengan sendirinya (secara alami). ${ }^{2}$

\section{Penelitian dikaitkan dengan kanker}

Pada Tahun 2018 muncul kasus dan mulai dilakukan penyelidikan oleh Dr.Swee Tan bersama Tim mengenai Strawberry Birthmarks, serta mengarah pada pengobatan yang berpotensi efektif, terjangkau, dan mudah diakses untuk berbagai jenis kanker.

Dalam pembicaraan ini, Dr. Tan membahas bagaimana pengobatan revolusioner ini ditemukan, dan bagaimana pengobatan ini dapat mengubah masa depan perawatan kanker bagi dunia. ${ }^{3}$

\section{Terapi menggunakan teknik stem cell}

Stem cell berasal dari plasenta bayi saat lahir, dan dari plasenta dapat menemukan selsel induk. Stem cell disini dapat dikendalikan sistem hormon yang dimiliki atau disebut sistem renin-angiotensin yang mengontrol tekanan darah 3. 
Penemuan ini menggaris bawahi cara kita untuk mengetahui dan memperlakukan Strawberry Birthmarks serta dalam pengobatan yang berpotensi efektif, terjangkau dan mudah diakses untuk berbagai jenis kanker.

Penggunaan obat salah satunya yaitu penggunaan dan ACE inhibitor. Kasus pada bayi berusia 3 bulan memiliki Strawberry Birthmarks di rongga mata dan kemudian dilakukan pengobatan menggunakan Propanolol yang merupakan salah satu golongan selama 5 bulan pengobatan, mengalami proses penyembuhan. ${ }^{3}$

Kasus selanjutnya ada lima kasus yang sama untuk Strawberry Birthmarks berada pada wajah serta leher pada bayi berumur 1 bulan dengan dilakukan pengobatan mengguakan Captopril yang merupakan salah satu golongan obat ACE inhibitor dan mengalami proses penyembuhan setelah 4 bulan pengobatan. ${ }^{3}$

Pengembangan obat baru akan menelan biaya 12 dari 1 milyar. Untuk pengembangan dan pengambilan rata-rata 12 tahun agar bisa launching ke pasar, dan memiliki peluang 1:10.000 untuk itu Dr. Tan beserta Tim membayar lebih banyak untuk pengembangan obat baru tersebut, biaya obat merupakan sebagian kecil dari dan lebih sedikit waktu dan kemungkinan lebih banyak penyakit kanker yang berhasil. ${ }^{3}$

Kanker merupakan penyebab utama kematian manusia yang sangat besar dengan faktor biaya ekonomi menjadi salah satu yang mempengaruhi dan penyakit ini merupakan penyakit ke-3 di kesehatan dunia. Organisasi memperkirakan pada 2018 ada 18 juta kasus baru, dan Selandia baru ditemukan ada 25.000 kasus, dan kasus kanker diatas

11.000 merupakan kanker kulit non-melanoma pada tahun 2035 memprediksi dan akan terjadi peningkatan sebesar $50 \%$ hal ini disebabkan terjadinya peningkatan populasi menua dan meningkatnya jumlah populasi itu sendiri yang dapat mengubah gaya hidup. $^{3}$

\section{Terapi kanker konvensional}

Pengobatan konvensional untuk kanker biasanya meliputi radioterapi dan operasi, serta kemoterapi. Kemoterapi saat ini sangat invasif dan menyebabkan hilangnya kualotas hidup dan sebagian efektif, pasien kanker rata-rata $40 \%$ pasien akan mati dalam waktu lima tahun meskipun dalam pengobatan radikal, biaya fisik pengobatan kanker mencapai 1 milyar setahun dan mengalami peningkatan yang cepat yang disebabkan oleh faktor populasi menua dan peningkatan jumlah populasi itu sendiri sehingga mengakibatkan meningkatknya biaya obat baru, yang diharapkan efektif dalam biaya rendah dan kurang invasif pada perawatan yang dibutuhkan 3 .

Konsep kanker yang berlaku atau sering disebut dengan model kanker stokastik. Kanker stokastik ini mengusulkan model bahwa kanker berkembang karena adanya satu sel normal didalam tubuh kita yang akan mengalami mutasi dan menjadi sel kanker. 
Sel kanker juga akan mengalami replikasi atau penggandaan atau salinan untuk membentuk sel-sel membentuk tumor. Sehingga peneliti terfokus pada pengobatan sel kanker. $^{3}$

Tubuh kita terlalu sulit untuk melawan dan membunuh sel kanker, dalam lima tahun terakhir peneliti melakukan dan telah menerapkan pemahaman tentang tanda lahir Strawberry dan dilakukan penyelidikan kanker oleh adanya pendekatan radikal berdasarkan sel induk yang datang atau masuk dalam kanker.

Konsep sel induk juga disebut dengan model kanker hierarki, dan jika kita bayangkan sel induk kanker itu seperti seperti sarang lebah. Didalam sarang lebah terdapat lebah pekerja. Jika dilihat lebih dalam lagi terdapat seorang pemimpin yaitu ratu lebah.

\section{Konsep terapi kanker baru}

Ratu lebah menjadi alasan mengapa ada sarang lebah yang ditimbulkan. Lebah pekerja didalam sarang lebah merupakan sel kanker tetapi ratu lebah juga dapat membuat salinan yang sama, dan setelah itu menjauh dan membuat sel-sel induk yang lain.

Sehingga sel kanker disini akan terjadi pengulangan secara lokal. Kita tahu bahwa selsel induk kanker ini menolak untuk dilakukan kemoterapi dan radioterapi sehingga secara lambat kanker akan kembali lagi setelah bertahun-tahun 3 .

Berdasarkan konsep ini kami melihat jumlah kanker paru-paru yang berbeda dengan kanker pertama yang kami lihat di lidah.

Kanker lidah merupakan kanker terburuk dimulut menunjukkan adanya sel induk kanker pada garis berwarna hijau dengan penanda CD4T untuk sel induk kanker dan penanda tersebut manandai membran sel. Dan secara garis besar dari masing-masing sel disana.

Red Sox merupakan sel induk embrionik sebagai penanda dari batang kanker ini dan memili sel-sel titik biru yang sama dengan inti sel sehingga sel-sel ini memiliki sifat seperti sel induk embrionik, warna hijau sebagai penanda lain dari batang kanker dan sel tersebut dapat mengekspresikan sistem renin-angiotensin yang merupakan salah satu dari komponen yang disebut reseptor pro-irania.

Warna merah merupakan sejumlah komponen utama yang dinyatakan oleh sel induk kanker, jika melihat dua gambar ini warna orange dalam warna merah ditambah dengan warna hijau dengan warna jingga menyatakan bahwa batang sel kanker lidah secara langsung mengungkapkan sistem renin-angiotensin yang ditemukan sama pada Strawberry Birthmarks. ${ }^{3}$ 


\section{Strawberry dan sel kanker}

Pada Strawberry Birthmarks dimana menunjukkan keberadaan batang sel kanker mengekspresikan sistem renin-angiotensin pada melanoma bentuk kanker mematikan lainnya dan juga glioblastoma lain yang sangat agresif. Dan jika akan mengambil sepotong sel kanker otak dan ditumbuhkan didalam laboratorium dengan waktu 2-3 minggu warna yang dihasilkan akan seperti warna coklat-kecoklatan dan ini adalah selsel induk kanker didalam jika berbentuk seperti bola.

Bentuk kanker ini merupakan karakteristik dari kanker. Sel induk dapat menumbuhkan batang kanker dan kemudian sel keluar dari sampel jaringan kanker, sel-sel induk memiliki penanda yang memugkinkan untuk melakukan identifikasi.

Empat penanda kanker digunakan dalam sebuah penelitian untuk menunjukkan bahwa ini merupakan sel-sel induk kanker. Konsep yang diharapkan menemukan hal yang sama di semua jenis kanker, dan kami juga telah menunjukkan dengan adanya kanker itu sendiri, kanker dapat mengekspresikan pada sistem pengaturan umum yaitu sistem renin-angiotensin 14 jenis kanker yang dapat mempengaruhi sebagian besar sistem organ utama.

Sistem renin-angiotensin dapat diblokir dengan obat sederhana yang biasanya diresepkan oleh dokter, jika komsep ini benar apa yang terjadi jika pasien yang meminum obat ini selama 20 tahun terakhir berupa publikasi menunjukkan pasien menggunakan salah satu obat tersebut, memiliki kelangsungan hidup yang lebih baik dari sebelumnya atau kemungkinan kurang untuk mengembangkan. ${ }^{3}$

Meta analisis yang diterbitkan pada tahun terakhir menganalisa terdapat 55 studi Duke I yang menunjukkan pasien kanker itu menggunakan salah satu obat dan $20 \%$ lebih sedikit mengalami kekambuhan dan kematian akibat kanker, berdasarkan dari kami yang bekerja di labolatorium dan menerbitkan apa yang kita dapat dengan kanker baru dan menargetkan perawatan terhadap kanker.

\section{Kesimpulan}

Kanker memiliki jalur utama yang terlibat didalamnya, dan memiliki dua jalur adanya reseptor faktor pertumbuhan insulin dan jalur COX-2 pada obat yang dapat memblokir jalur ini dan yang terjadi pada pasien dalam menggunakan obat seperti Metformin yang digunakan untuk penyakit diabetes dan anti-inflamasi non steroid, dan apabila aspirin digunakan pada pasien dan meminum obat-obat yang tertulis, hal ini akan menujukkan bahwa pasien berada pada salah satu dari mereka yang cenderung mendapatkan penyakit kanker.

Sel-sel ratu lebah bukan lagi kanker, tetapi sel kanker yang menggunakan kombinasi obat dan tidak mematenkan obat-obat serta menargetkan sistem renin-angiotensin, dan kita telah mendapat persetujuan etika dan persetujuan Scott untuk melanjutkan uji klinik untuk menutupi glioblastoma, kanker mulut, melanoma dan metastatis, di rumah sakit squamosa kanker telah menyetujui untuk melakukan penelitian, sekarang telah merekrut pasien glioblastoma, penelitian ini akan berlangsung selama tiga tahun. ${ }^{3}$ 


\section{Kesimpulan}

Kami percaya pada akhirnya kami dapat menunjukkan apakah ini efektif atau tidak. Glioblastoma merupakan kanker yang diderita orang-orang dan mereka melakukan pengobatan secara konvensional meliputi operasi, kemoterapi, dan radioterapi dengan biaya 60.000 dollar/tahun. Meskipun dengan perawatan radikal atau pengobatan radikal ini setengah dari pasien akan mati dalam 50 bulan dan hanya $5 \%$ dari pasien yang selamat.

Harapan bahwa studi ini akan kita wujudkan dan bermanfaat bagi pasien dengan glioblastoma di Selandia Baru dan bermanfaat secara global 3.

\section{Daftar Pustaka}

1. Adrian K. Penyebab Timbulnya Tanda Lahir pada Bayi - Alodokter. 7 Maret 2018. https://www.alodokter.com/penyebab-timbulnya-tanda-lahir-pada-bayi. Published 2018. Accessed May 26, 2019.

2. Strawberry Hemangioma pada Luna - The Urban Mama. https://theurbanmama.com/articles/strawberry-hemangioma-f10593.html. Accessed May 26, 2019.

3. Tan S. (75) Strawberry Birthmarks and a radical way of looking at cancer | Swee Tan | TEDxAuckland - YouTube. https://www.youtube.com/watch?v=4VkObs1J7Q8. Accessed May 26, 2019. 